\title{
Perceptions and Expected Immediate Reactions to Severe Storm Displays
}

Ihnji Jon ${ }^{\mathrm{a}}$

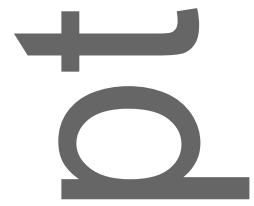

Shih-Kai Huang

Michael K. Lindell ${ }^{\mathrm{c}}$

a Department of Urban Design and Planning, University of Washington, Box 355740 Seattle, WA 98195-5740; ihnjijon@uw.edu; 415-696-1756

${ }^{\mathrm{b}}$ Department of Emergency Management, Jacksonville State University, Anniston AL 36205;

shuang@jsu.edu; 979-308-9985

${ }^{\mathrm{c}}$ Department of Urban Design and Planning, University of Washington, Box 355740 Seattle, WA

98195-5740; mlindell@uw.edu; 206-369-7931

Perceptions and Expected Immediate Reactions to Severe Storm Displays

\section{Abstract}

The National Weather Service has adopted warning polygons that more specifically indicate the risk area than its previous county-wide warnings. However, these polygons are not defined in terms of numerical strike probabilities $\left(p_{s}\right)$. To better understand people's interpretations of warning polygons, 167 participants were shown 23 hypothetical scenarios in one of three information conditions-polygon-only (Condition A), polygon + tornadic storm cell (Condition B), and polygon + tornadic storm cell + flanking nontornadic storm cells (Condition $\mathrm{C}$ ). Participants judged each polygon's $p_{s}$ andreported the likelihood of taking nine different response actions. The polygon-only condition replicated the results of previous studies; $p_{s}$ was highest at the polygon's centroid and declined in all directions from there. The two conditions displaying storm cells differed from the polygon-only condition only in having $p_{s}$ just as high at the polygon's edge nearest the storm cell as at its centroid. Overall, $p_{s}$ values were positively correlated with expectations of continuing normal activities, seeking information from social sources, seeking shelter, and evacuating by car. These results indicate that participants make more appropriate $p_{s}$ judgments when polygons are presented in their natural context of radar displays than when they are presented in isolation. However, the fact that $p_{s}$ judgments had moderately positive correlations with both sheltering (a generally appropriate response) and evacuation (a generally inappropriate response) suggests that experiment participants experience the same ambivalence about these two protective actions as people threatened by actual tornadoes.

Keywords:Tornado warning polygons; risk perceptions; protective actions

This is th auth $\mathrm{r}$ manuscript accepted for publication and has undergone full peer review but has not been throug 1 copyediting, typesetting, pagination and proofreading process, which may lead to differences between this version and the Version of Record. Please cite this article as doi: 10.1111/risa.12896.

This article is protected by copyright. All rights reserved. 


\section{INTRODUCTION}

Tornadoes are a hazard in the US, with a peak of 553 casualties in a single year. ${ }^{(1)}$ Thus, the National Weather Service (NWS) is attempting to improve its warnings so people respond more appropriately before tornadoes strike. ${ }^{(2)}$ In particular, the NWS has changed from county-wide warnings to storm-based warnings that identify risk areas by polygons. To date, few studies have examined the strike probability $\left(p_{s}\right)$ judgments and expected responses that warning polygons elicit. To address this deficiency in the tornado response literature, this study proposes a series of research hypotheses and research questions based on previous tornado warning research and describes an experiment in which participants viewed 23 hypothetical scenarios and then reported their $p_{s}$ judgments and expected responses to those scenarios. To replicate the results of Lindell and his colleagues, ${ }^{(3)}$ one group of participants viewed scenarios that displayed only a warning polygon. To extend the results of that study, a second group viewed scenarios that displayed a warning polygon and a single tornadic storm cell, whereas a third group viewed scenarios that displayed a warning polygon, a tornadic storm cell, and two flanking nontornadic storm cells. The following sections review previous studies on tornado warning response and tornado warning polygons, propose a series of research hypotheses and research questions derived from this research, describe the methods of data collection and analysis, present and discuss the experimental results, and summarize the study's conclusions.

\section{LITERATURE REVIEW}

\subsection{Tornado Warning Response Studies}

Consistent with the Protective Action Decision Model, ${ }^{(4-6)}$ tornado research has found that people respond to warnings in a variety of different ways. ${ }^{(7,8)}$ This research has concluded that warning message characteristics significantly affect people's protective responses, especially when they are imprecise regarding the potential impact severity, location, and time. ${ }^{(9)}$ Thus, people are more likely to take appropriate protective action in response to messages that provide specific information about a tornado path, ${ }^{(10)}$ visually depict the severity of tornado impacts ${ }^{(11)}$ and provide protective action guidance. ${ }^{(12)}$

Many people try to confirm tornado warnings by seeking information from social sources (turning on radio or TV, contacting authorities or peers, using social media or weather information websites) and, especially, by going outside to look for environmental cues. However, people differ in the amount of information they expect before taking protective action. In one study, a warning alone was sufficient for $40 \%$ of the respondents, whereas $34 \%$ wanted more information about location and intensity, and $39 \%$ wanted confirmation from environmental cues such as hearing or seeing tornado or other cues such as heavy rain and strong wind. ${ }^{(13)}$

When people decide to shelter, they seek the most readily available protective location-such as an aboveground interior room, a basement, or a safe room or storm shelter. If they do not possess adequate shelter, some people leave their homes to shelter with neighbors or evacuate from the risk area. For example, respondents' most common response to their most recent tornado warning was to shelter in the basement (69\%), but many continue current activities (12\%) or seek additional information (13\%) ${ }^{(13)}$ Durage et al. ${ }^{(14)}$ reported that respondents' mean ranks of their expected response to tornado were highest for sheltering (1.47) and much lower for continuing current

This article is protected by copyright. All rights reserved. 
activities (3.47) or driving away (3.70). Of those who received a warning during the Joplin tornado, $77 \%$ took shelter ${ }^{(15)}$ whereas another study found that only $18 \%$ of respondents would leave their houses to escape an oncoming tornado. ${ }^{(16)}$ Finally, two national surveys found that-in response to a tornado warning-most people would shelter in their residence or on their property (67\% in 2012 and $66 \%$ in 2013), a significant percentage would move to nearby location or drive away (24\% and $23 \%$, respectively), and only a few would continue their current activities $-9 \%$ and $11 \%$, respectively.

\subsection{Tornado Warning Message Studies}

A growing number of experiments have examined the effects of different components of tornado warning messages, including their verbal content, radar displays, and warning polygons. For example, Casteel ${ }^{(18)}$ found that experiment participants who received impact-based warnings (IBWs), which provide detailed verbal descriptions of the potential effects of a tornado, had greater expectations of sheltering in-place. Information about the hazard (e.g., a tornado), the data source on which the warning was based (radar or ground spotter) and potential impact (e.g., severity of damage to mobile homes, site-built houses, vehicles, and exposed people and animals) increased the likelihood of taking protective action. However, the evidence in support of IBWs is not all positive. The Ripberger et al. ${ }^{(11,17)}$ study of IBWs found that increasing levels of impact had a stronger effect on evacuation (an inappropriate action) than on sheltering in-place (the NWS recommendation). Perreault, Houston and Wilkins $(2014)^{(19)}$ found that IBWs were perceived to be less credible than conventional warnings but had no effect on expectations of taking protective action. Mason and Senkbeil ${ }^{(20)}$ developed a six category Tornado Watch Scale (TWS) that provides guidance about the types of shelter that are adequate, questionable, or inadequate for that tornado category. Their test of the TWS on a convenience sample of 38 Alabama residents showed that respondents' expected behavior tended to change toward greater safety after hearing scenarios, which were described initially using typical NWS language and later framed in terms of the TWS. Moreover, when asked about their preference for the typical NWS language or the TWS, 37 (97\%) of the respondents picked the TWS.

Other studies have assessed the effects of visual displays on warning recipients. Drost et al. ${ }^{(21)}$ found that an animated video was superior to a traditional TV presentation and an audio-only presentation of warning information in its impact on recipients' retention of information contained in the warning message. Sherman-Morris and Lea ${ }^{(22)}$ tested the impact of two different types of radar images on warning recipients. They found that respondents who viewed a reflectivity display had higher perceptions of risk and higher expectations of shelter in-place than those who viewed a velocity display. However, the researchers concluded that other aspects of the data suggested that these differences were due to the weathercasters' accompanying commentary rather than the images themselves. Finally, Stokes and Senkbeil ${ }^{(23)}$ focused on information sources and channels, but they did note that 21 percent of their respondents cited being able to view the tornado track on television or website was an important determinant of sheltering in-place.

In addition, six experiments have examined people's responses to tornado warning polygons, one of which presented a tornado warning polygon and asked 29 respondents to indicate its likelihood of striking different areas. ${ }^{(24)}$ An ellipse in the polygon's center was perceived to be the 
area of greatest risk. Another study compared the conventional polygon with two alternatives. ${ }^{(25)}$ The conventional tornado polygon essentially treats the entire area within the polygon as having the same level of risk, whereas the authors' spectral display divides a polygon into nine areas and indicates the highest risk in dark red, the lowest risk in light blue, and intermediate risk levels using different hues of the color spectrum. The third format was a gradient display that divides a polygon into five areas indicating the highest risk in dark red and the other areas in gradually lighter shades of red. Data from 501 participants indicated that the conventional polygon elicited the highest ratings of fear and likelihood of taking protective action, particularly at the polygon centroid, and both dependent variables declined sharply near the polygon edges. In the spectral and red gradient formats, there were much larger areas of high ratings on both dependent variables-especially at the polygon edge closest to the storm front. The spectral and gradient polygons had ratings on both dependent variables that tended to decrease more gradually toward the outer contour than was the case for the conventional polygon.

Klockow ${ }^{(26)}$ showed 35 interviewees storm radar images and four types of warning polygonsone of them deterministic (the conventional polygon) and the other three probabilistic ellipsoids that varied in their color coding-each superimposed onto a regional map. All displays contained four locations that were on a straight line and were at increasing distances from the storm front. These four points were identified in the probabilistic displays as being in the $75^{\text {th }}, 60^{\text {th }}, 45^{\text {th }}$, and $30^{\text {th }}$ percentile $p_{s}$ regions. Interviewees were asked to interpret the four displays and describe their expected response at each of the four points. In general, they expected to shelter only in the highest probability regions. The lower probability regions tended to elicit expectations of situational monitoring and preparedness actions, but some respondents expected to ignore the storm and resume previous activities. In a follow-up study, 5564 participants were randomly assigned to the cells of a 2 (verbal probability label) $\times 6$ (display type) experimental design. The verbal probability labels were "high" vs. "low". Two of the displays were deterministic; one was a "short warning" that included only the two closest locations and the second was a "long warning" that included all four locations. The remaining four displays were all probabilistic but varied in their color schemes. The continuous scheme corresponded to the Ash et al. ${ }^{(25)}$ red gradient display and the qualitative scheme corresponded to the Ash et al. ${ }^{(25)}$ spectral display. The last two display types were a divergent scheme and a "colorless" scheme. In the divergent scheme, the highest risk area was dark orange, the lowest risk area was dark blue, and intermediate levels of risk were indicated by light orange, white, and light blue. In the "colorless" scheme, areas within the contours were unshaded. All participants assumed the role of an airport manager and went through 96 trials in which they used the tornado information displays to decide whether to shelter aircraft from the approaching storm. The results revealed substantial similarity among the different displays, especially among the colored probabilistic displays. Moreover, examination of a receiver operating characteristic diagram showed that the colored probabilistic displays produced lower false positive rates, especially when they were accompanied by verbal labels.

The fourth experiment presented each of 64 participants with 24 tornadoes, each presented in one of four formats - text only, text + warning polygon, text + radar image, and text + warning polygon + radar image on a simulated smart phone screen. ${ }^{(27)}$ The text message described a tornado warning for the respondent's area, the warning's expiration time, and a shelter recommendation. 
Surprisingly, the results showed that addition of graphical information (radar image and warning polygon) to text information produced no increase in participants' ratings of perceived severity, perceived risk, and likelihood of contacting loved ones.

The fifth experiment used 36 participants in an experiment that examined four polygons-a four-color (red, orange, yellow, green) spectral display, a red gradient display, a gray gradient display, and a contour display (the areas within the contours were unshaded, as in Klockow's "colorless" display), which were presented either with or without a radar image of the generating storm. ${ }^{(28)}$ The dependent variables were the participants' $p_{s}$ judgments, and their levels of agreement (on a five-category Likert scale) of being impacted, fearing for life and property, and protective action expectation. The results showed that displays without radar images elicited faster responses for the spectral, red gradient, and contour displays but not the gray gradient display. Moreover, the displays without radar images were more accurate for the $p_{s}$ judgment, likelihood of being impacted, fear, and protective action expectations. There were no significant differences among the display types without radar images, but the gray scale elicited significantly more accurate responses when a radar image was displayed. When asked about their preference, the participants overwhelmingly picked the spectral display.

The most recent study presented 155 participants with 15 different warning polygons. ${ }^{(3)}$ All participants were told that NWS guidance indicates people should take protective action inside-but not outside-the warning polygon and they should imagine they had checked into a motel where they were watching the evening news when they were informed of a tornado warning. After viewing each polygon, participants provided $p_{s}$ ratings and the likelihood of taking nine different response actions ranging from continuing current activities to getting in a car and driving somewhere safer. The results suggested a proximity heuristic in which participants inferred that $p_{s}$ was highest at the polygon's centroid, lower just inside its edges, still lower (but not zero) just outside its edges, and lowest in loeations beyond that. Higher $p_{s}$ judgments were associated with lower expectations of continuing previous activities and higher expectations of seeking information from social sources (but not environmental cues) and higher expectations of seeking shelter (but not evacuating).

\subsection{Effects of Respondents' Personal Characteristics}

Some tornado studies have examined the effects of personal characteristics, such as experience and demographic variables, on tornado warning response. Personal experience with previous events makes people more likely to believe and respond to tornado warnings. ${ }^{(29)}$ Those who have previously seen tornado warning polygons were less likely to ignore tornado threats and those who have previously ignored a tornado warning were more likely to provide lower $p_{s}$ judgments, be more likely to ignore the warning, and be less likely to confirm the warning and shelter immediately. ${ }^{(3)}$ Just over half (51\%) of those who experienced both the 1999 and 2003 Moore Oklahoma tornadoes took the same action on both occasions; those took less protective action in the second tornado were offset by an equal percentage who took more protective action. ${ }^{(30)}$ Based on their experience in the 27 April, 2011 tornado, almost two-thirds (62\%) of Tuscaloosa respondents expected to change their tornado shelter plans. ${ }^{(31)}$

Examination of demographic variables has found that having at least a high school degree is positively related to responding to a warning message ${ }^{(32-34)}$ Females are more likely than males to 
provide high $p_{s}$ judgments, avoid warning confirmation from environmental cues, and to shelter in safe locations ${ }^{(3,17,30,35)}$ but there is conflicting evidence on their tendency to seek warning confirmation from social sources. Finally, there is mixed evidence on the effect on tornado warning response of age ${ }^{(36,37)}$ and race..$^{(3,31,37)}$

\subsection{Implications of Tornado Research Findings}

The results of previous research suggest people use a proximity heuristic when responding to tornado warning polygons. This heuristic produces a perceived risk gradient that has $p_{s}$ decreasing as a function of distance from the expected impact location. ${ }^{(38)}$ Thus, people are expected to make three categories of $p_{s}$ judgments. The first category comprises locations within the polygon, with lower $p_{s}$ judgments in locations near the lateral edges than in those near the centroid. ${ }^{(3,24,25)}$ The second category comprises locations just outside the polygon, which have lower-but not zero- $p_{s}$ judgments. ${ }^{3+}$ In addition, the third category comprises locations farther outside the polygon. Finally, two of these studies suggest that participants' $p_{s}$ judgments and emotional reactions are consistent with their behavioral expectations of taking protective action. ${ }^{(3,25)}$

One limitation of some tornado polygon studies ${ }^{(3,24,25)}$ is that the participants saw polygons only and not radar displays of the storm cells that were the basis for the polygons. The absence of this contextual information could explain why $p_{s}$ judgments are highest at the polygon's centroid rather than at the edge of the polygon that is nearest the storm cell. One study that displayed radar images of the relevant storm cell found no effect of this information ${ }^{(27)}$ and another found a negative effect. ${ }^{(28)}$ However, this might be due to the fact that the first study had a small sample and only presented participants' location at the polygon's centroid. The second study also had a very small sample and only reported overall accuracy rather than $p_{s}$ judgments at specific locations. Thus, it is necessary to develop a better understanding of people's interpretations of tornado polygons by conducting a replication and extension of Lindell et al. ${ }^{(3)}$ that shows some participants a polygon-only (the replication) and shows other participants polygons in the more natural context of the radar displays of the storm cells that are the basis for the polygons (the extension). Replication of previous results is important because recent publications have emphasized the prevalence of spurious findings in behavioral research and the need for replications to confirm that reported effects are reliable. ${ }^{(39,40,41)}$ Extension is important to determine if previous tornado polygon results can also be found in when the context is changed.

It is also important to continue examining the relationship of people's personal characteristics to $p_{s}$ judgments and protective action expectations. These include female gender ${ }^{(42-44)}$ and hazard experience ${ }^{(30,33,45)}$. It is also important to assess participants' perceptions of the personal consequences of a tornado's impact because these have the strongest correlations with behavioral expectations and actual behavior in response to hurricanes. ${ }^{(46)}$ Finally, it is important to determine if people's numerical interpretations of verbal probability labels are related to their numeracy because an extensive body of research has shown that low numerates have difficulty in processing quantitative risk information. ${ }^{(47-50)}$ Although low numerates' processing of graphical depictions of quantitative risk information differs from that of high numerates, they are equally capable of drawing correct inferences from that information. ${ }^{(51)}$ It is unclear what implications these findings have for tornado warnings because the existing literature on numeracy has focused on individualized

This article is protected by copyright. All rights reserved. 
communication of risk for diseases whereas tornado warnings involve mass communication of risk for an environmental event. One possibility is that people with lower levels of numeracy have different ways of expressing-as opposed to interpreting-probabilities.

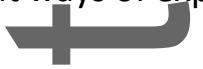

\subsection{Research Hypotheses and Research Questions}

The research literature summarized in the previous sections leads to nine research hypotheses and three research questions.

RH1: Tornado $p_{s}$ judgments will be greater at the polygon centroid than inside its lateral and far edges.

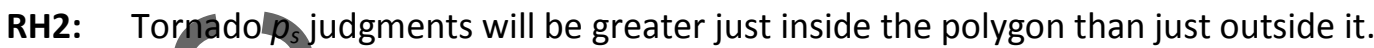

RH3: Tornado $p_{s}$ judgments will be greater just outside the polygon than at a moderate distance outside it

RH4: Tornado $p_{s}$ judgments will be greater at a moderate distance outside the polygon than much farther outside it.

RH5: Tornado $p_{s}$ judgments will be highest at the polygon centroid for the polygon-only display but will be highest at the edge nearest a tornadic storm cell when a radar image is added.

RH6: Tornado $p_{s}$ judgments will be higher outside the polygon when minor storm cells are added on either side of a tornadic storm cell.

RH7: Tornado $p_{s}$ judgments will be significantly correlated with expected response actions.

RH8: Prior experience with tornado warnings, warning polygons, or tornado damage will be significantly related to $p_{s}$ judgments and expected response actions.

RH9: Gender and ethnicity will be significantly related to $p_{s}$ judgments and expected response actions.

RQ1: What are the expected personal consequences of a tornado strike?

RQ2: Is there a significant correlation of the expected personal consequences of a tornado strike with $p_{s}$ judgments and expected response actions?

RQ3: Is numeracy related to $p_{s}$ judgments and expected response actions?

\section{RESEARCH METHOD}

\subsection{Participants}

Data were collected from student volunteers at the University of Washington in April 2016 according to an approved IRB protocol; each was paid \$20. There were 180 volunteers who registered, but only 167 participated. Overall, the sample was predominantly female (67\%) and single (98\%), with an average age of 22.5. They were most likely to identify themselves as Asian or other Pacific Islanders (59.3\%), following by Caucasians (29.3\%), African Americans (5.4\%), Hispanics (5.4\%), and Native Americans (0.6\%). Only a minority had previously seen a tornado polygon (24.0\%). Among those who had experienced tornado warnings $(n=42), 81 \%$ had taken a protective action at least once, whereas $62 \%$ of them had ignored a warning at least once. Very few participants had previous tornado damage experience (0.65 on a scale $0-7$ ).

\subsection{Procedure}

Participants read from a screen at the front of the room and listened as an experimenter read aloud a description of the color codes in NWS radar displays (in the two radar display conditions but 
not the polygon-only condition). They also read from a handout as the experimenter read aloud the NWS's description of tornado warning polygons that were originally found on the NWS website at www.srh.noaa.gov/images/bmx/aware/swaw 2010/web version pages p6.pdf but are reproduced in Appendix A. Next, the experimenter displayed on the screen and read aloud a scenario in which participants were told to assume they had checked into a single story motel in Des Moines lowa at 5:30pm. While unpacking, a TV newscaster warned of thunderstorms moving northeast at $20 \mathrm{mph}$ and a NWS tornado warning between 6-9pm. The simulated broadcast displayed a tornado polygon defined by a red isosceles trapezoid and the motel location designated by a single blue dot (see Figure 1 for a scenario displaying the polygon in relation to a tornado storm cell and two flanking cells). Figure 2 summarizes the locations of the motel (blue dot) in relation to the tornado polygon, which was the same size and orientation in all 23 scenarios. For example, one scenario showed a single blue dot located at F2, another showed a single blue dot located at F3, and so on. To be consistent with the participant's frame of reference (always located at the model in Des Moines), the blue dot was always located at the center of the screen and the location of the polygon varied.

The polygon-only display (Condition A) showed only the blue dot and the polygon without any storm cells (i.e., Figure 1 without a radar display). In Condition B, this information was supplemented by a simulated radar display showing a storm cell with a hook echo (i.e., Figure 1 with only the central storm cell). Finally, in Condition $C$, the blue dot, polygon, and tornadic cell were supplemented by a simulated radar display showing a tornadic storm cell (as in Condition B) with the addition of two flanking non-tornadic storm cells (i.e., Figure 1). Each participant viewed all 23 hypothetical tornadoes but viewed only one type of display (i.e., display was a between-subjects manipulation). As shown in Figure 1, each warning polygon's far edge (the one farthest from the storm front) was longer than its near edge, indicating increasing uncertainty about $p_{s}$ with time and distance. The radar display of the tornadic storm cell had colors ranging from blue through green, yellow, and orange to red. Furthermore, as described to the participants, the tornadic storm cell's hook echo indicated a circular wind rotation that signals tornado formation. By contrast, the two flanking storm cells only had colors ranging from blue to green. The participants were given no information about tornado intensity.

After viewing each display, participants judged the likelihood of the tornado striking them (5point scale ranging Extremely unlikely $=1$ to Extremely likely $=5$ ). They also used this scale to rate their likelihood of taking each of nine different response actions. According to the NWS, the most appropriate response for those inside the polygon, but not those outside it, is to seek shelter in an interior room or hallway. It is less appropriate for those inside the polygon to seek additional information by watching the weather forecast on TV, try to get more information from the motel desk clerk, or try to get more information on the Internet. All of these delay implementation of the appropriate response. The least appropriate responses for those inside the polygon are to ignore the weather forecast and continue what they were doing, go outside to see if a tornado is coming, or get into a car and drive someplace safer. There was no constraint on the amount of time the participants could take to complete their responses to each hypothetical tornado.

After responding to all 23 tornado scenarios, participants answered four sets of questions measuring their expected personal consequences of a tornado strike, their previous experience with tornadoes, a scale of subjective numeracy, and their demographic characteristics. As in Lindell et 
al. ${ }^{(3)}$, participants used a 5-point scale to rate the likelihood their room would be severely damaged or destroyed, their car would be severely damaged or destroyed, their luggage would be severely damaged or destroyed, and they would be severely injured or killed.

Participants reported previous tornado warning experience in terms of having seen a warning polygon on TV $(\mathrm{NO}=0, Y e s=1)$, having taken protective action after receiving a tornado warning and $(N o=0, Y e s=1)$, and having taken no protective action after receiving a tornado warning (No $=0$, Yes $=1$ ). Participants reported previous tornado impact experience with tornado property damage in their city ( $N o=0$, Yes $=1)$, damage to their home $(N o=0$, Yes $=1)$, damage to the home of a friend, relative, neighbor, or coworker they know personally (No $=0$, Yes $=1$ ), injury to themselves or members of their immediate family ( $N o=0, Y e s=1)$, injury to a friend, relative, neighbor, or coworker they know personally ( $N o=0, Y e s=1$ ), disruption to their school that prevented them from attending (No = $0, Y e s=1$ ), and disruption to their shopping and other daily activities ( No $=0$, Yes $=1$ ). These seven items were summed to produce a measure of previous tornado damage experience, which resulted in a scale with $\alpha=.79$. Numeracy was measured using the Subjective Numeracy Scale ${ }^{(53)}$ The eight items were summed to form a scale whose reliability was $\alpha=.67$.

Participants were also asked to report their age (Under $21=1,21-25=2,26-30=3,31-35=4$, and Over $35=5$ ), gender (Male $=0$, Female $=1$ ), and ethnicity (African Americans $=1$, Asian or other Pacific Islanders $=2$, Caucasian $=3$, Hispanics $=4$, and Native American $=5$ ). Ethnicity was subsequently recoded to Minority $(=0)$ and White $(=1)$. In addition, participants were asked to report their marital status (Married $=1$, Single $=2$, Divorced $=3$, and Widowed $=4$ ), education level (Some high school $=1$, High school graduate $/ G E D=2$, Some college/vocational school $=3$, College graduate $=4$, Graduate school $=5$ ), income level (Less than $\$ 25,000=1, \$ 25,000-49,999=2$, $\$ 50,000-74,999=3, \$ 75,000-99,999=4, \$ 100,000$ or more $=5)$, and homeownership (Rent $=0$, Own $=1$ ). Finally, they reported the numerical probability that they would assign to each of the scale's five verbal labels (extremely unlikely, moderately unlikely, even odds, moderately likely, and extremely likely) on a scale from Impossible $(=0)$ to Absolutely certain $(=100)$.

\section{RESULTS}

\subsection{Treatment of Missing Data}

Overall, 96.4\% (161/167) of participants completed all questionnaire items, and the others omitted only a single item. The highest missing data rate was $3.6 \%$ (ethnicity with six values missing). Little's ${ }^{(53)}$ MCAR (missing completely at random) test yielded a nonsignificant result $\left(\chi_{5200}^{2}=285.5, p\right.$ $=1.000$ ), indicating the missing values were completely at random. Thus, the ExpectationMaximization (EM) algorithm in SPSS 17.0 was used to estimate the missing values.

\subsection{Data Processing}

This experiment yielded three sets of mean $p_{s}$ judgments (over the 167 participants) for each of the 23 hypothetical tornados-one set of means for each of the three display conditions. Figure 2 displays these mean $p_{s}$ judgments in a 5 rows by 12 columns matrix indicating the motel's location in relation to the polygon for each of the 23 hypothetical tornado scenarios. To test RH1-RH4, the differences in mean $p_{s}$ judgments between locations were assessed using $t$-tests. The differences between pairs of grid cells and their associated test results are presented in Table I. To test RH5-RH6,

This article is protected by copyright. All rights reserved. 
tornadoes were divided into six groups-motel located at the polygon centroid (Grid cell F3), motel located at the polygon's edge nearest the tornadic cell (Grid cell E2, F2, and G2), motel located in the polygon's two wings or edge farthest from the tornadic cell (Grid cells D3, H3, C4, F4, and 14), motel located just outside of the polygon (Grid cells D2, H2, C3, J3, B4, J4, and F5, and J5), motel located at a moderate distance outside of the polygon (Grid cells C2, 12, B3, J3, and A5), and motel located farthest outside of the polygon (Grid cell L4). Levene's tests indicated that the ratings were generally consistent within each group (the set of polygon's two wings and edge farthest from the storm cell in Condition C was the only exception). A Multivariate Analysis of Variance (MANOVA) was conducted to test the differences among the three display conditions. To test RH7-RH9, correlations were calculated among $p_{s}$ and expected response actions ratings for each of the tornado scenarios and the mean correlation between each pair of variables was calculated over those 23 scenarios (see Table II). To test RQ1, mean and interrater agreement $\left(r_{W G}\right)$ values were calculated for expected personal consequences. ${ }^{(54)}$ Finally, RQ2 and RQ3 were tested assessing correlations among the relevant variables. Because of the large number of statistical tests, $p \leq .01$ was selected as a statistical significance level.

\subsection{Tests of Research Hypotheses}

Consistent with RH1 (Tornado $p_{s}$ judgments will be greater at the polygon centroid than inside its lateral and far edges), Figure 2 shows that the polygon centroid (Grid cell F3) had significantly higher $p_{s}$ judgments than grid cells in the two wings (Grid cells D3 and H3) and the far edge of the polygon (Grid cells C4, F4, and 14). Table I shows that one of the hypothesized differences was significant at $p<.01$ and the rest were significant at $p<.001$.

Mostly consistent with $\mathrm{RH} 2$ (Tornado $p_{s}$ judgments will be greater just inside the polygon than just outside it), Eigure 3 shows that there generally were significantly higher mean ratings for grid cells just inside the polygon than for adjacent grid cells just outside the polygon. However, in Conditions B and C, a grid cell that was outside the polygon but close to its near edge ( $\mathrm{H} 2)$ was not significantly different from the adjacent grid cell inside the polygon (H3). Curiously, Table I shows that this nonsignificant difference was not found in the corresponding mirror image grid cells on the left side of the polygon (D2 and D3).

Mostly consistent with RH3 (Tornado $p_{s}$ judgments will be greater just outside the polygon than farther outside it), Figure 3 indicates that $p_{s}$ judgments were greater just outside the polygon than farther outside it in the polygon-only condition (Condition A) but there were nonsignificant differences between grid cells just outside the polygon and those farther outside the polygon in the two tornadic storm cell conditions (Conditions B and C). Specifically, there were nonsignificant differences between $\mathrm{I} 3$ and $\mathrm{J} 3$ in both conditions. As with the anomalous result for $\mathrm{RH} 2$, Table I shows that this nonsignificant difference was not found in the mirror image grid cells on the left side of the polygon ( $\mathrm{C} 3$ and $\mathrm{B} 3$ ).

Consistent with RH4 (Tornado $p_{s}$ judgments will be greater moderately far outside the polygon than much farther outside it), Figure 3 shows that respondents' $p_{s}$ judgments for grid cell L4 were much lower than for $\mathrm{J} 4\left(t_{59}=3.89, p<.001\right.$ for Condition $\mathrm{A}, t_{53}=5.90, p<.001$ for Condition $\mathrm{B}$, and $t_{52}=8.00, p<.001$ for Condition C). Indeed, although the mean $p_{s}$ judgment for L4 was not quite at 
the minimum $(M=1.0)$, it was quite close to this value because $59 \%$ of participants responded " 1 " and $33 \%$ responded " 2 ".

Mostly consistent with RH5 (Tornado $p_{s}$ judgments will be highest at the polygon centroid for the polygon-only display but will be highest at the edge nearest a tornadic storm cell when a radar image is added), a MANOVA revealed $p_{s}$ judgments varied by display type and tornado scenario group (Wilks' $\Lambda=.52, F_{12,318}=10.1, p<.001$ ). Specifically, Table I shows that $p_{s}$ judgments at the three grid cells within the near edge of the polygon (E2, F2, and G2) were significantly lower than those at the centroid (F3) in Condition A but not in Conditions B and C. By contrast, those three grid cells within the near edge of the polygon were not significantly different from the remaining grid cells within the polygon (D3, C4, F4, 14, and H3) in Condition A but were significantly different in Conditions B and C.

Contrary to RH6 (Tornado $p_{s}$ judgments will be higher outside the polygon when minor storm cells are added on either side of a tornadic storm cell), a MANOVA revealed nonsignificant differences in $p_{s}$ Judgments outside the polygon between Conditions B and C (Wilks' $\Lambda=.95, F_{6,100}=$ $.85, n s)$. Indeed, the mean difference between Conditions $\mathrm{B}$ and $\mathrm{C}$ in the $p_{s}$ judgments for the grid cells outside the polygon was extremely small-only $M_{A}-M_{B}=.08$.

Partially consistent with RH7 (Tornado $p_{s}$ judgments will be significantly correlated with expected response actions), Table II shows that $p_{s}$ judgments were negatively correlated with continuing normal activities $(r=-.44)$ and positively related to three information seeking activities (from TV, clerk, and Internet; $\bar{r}=.26)$, sheltering $(r=.50)$, and evacuating $(r=.38)$, but were nonsignificantly related to searching for environmental cues (going outside to see if a tornado is coming, $r=-.01$ ).

Partially consistent with RH8 (Prior experience with tornado warnings, warning polygons, or tornado damage-will be significantly related to $p_{s}$ judgments and protective action expectations), Table It shows that respondents with previous tornado warning experience who did not take protective actions were more likely to ignore the tornado warning in the experiment $(r=.23)$.

Partially consistent with RH9 (Gender and ethnicity will be significantly related to $p_{s}$ judgments and expected response actions), Table II shows that females and minorities produced significantly higher $p_{s}$ judgments ( $r=.20$ and $r=.28$, respectively) and were more likely to seek immediate shelter $(r=.26$ and $r=.22$, respectively). In addition, females were more likely to seek information from the Internet $(r=24)$ and evacuate $(r=.21)$. In addition, females and Whites were more likely to seek environmental cues by going outside ( $r=.20$ and $r=.20$, respectively).

\subsection{Tests of Research Questions}

Regarding RQ1 (What are the expected personal consequences of a tornado strike?), participants expected a tornado's personal consequences to be moderately ( $M=3.61)$ to extremely $(M=4.43)$ serious. Participants were significantly more likely to expect damage to the car than damage to the room $\left(t_{166}=3.66, p<.001\right)$, damage to luggage $\left(t_{166}=7.37, p<.001\right)$, and personal injury or death $\left(t_{166}=10.46, p<.001\right)$. In turn, they were more likely to expect damage to the room than damage to luggage $\left(t_{166}=5.00, p<.001\right)$, and personal injury or death $\left(t_{166}=9.48, p<.001\right)$. Finally, they were more likely to expect damage to luggage than personal injury or death $\left(t_{166}=4.30\right.$, $p<.001)$. The level of agreement about the likelihood of damage to the car $\left(r_{W G}=.62\right)$ or room $\left(r_{W G}=\right.$ 
.61) was higher than the level of agreement about injury or death $\left(r_{W G}=.41\right)$ and damage to the luggage $\left(r_{W G}=.43\right)$.

Regarding RQ2 (Is there a significant correlation of the expected personal consequences of a tornado strike with $p_{s}$ judgments and expected response actions?), three of the expected personal consequences of a tornado strike (car damage $r=.22$, luggage damage $r=.26$, and personal injury/death $r=24$ ) had significant positive correlations with $p_{s}$ judgments. In addition, those who perceived a greater likelihood of room damage $(r=.22)$ or injury/death $(r=.24)$ were more likely to evacuate.

Regarding RQ3 (Is numeracy related to $p_{s}$ judgments and expected response actions?), numeracy had nonsignificant correlations with $p_{s}$ judgments $(r=-.12, n s)$, continuing normal activities $(r=.18$, $n s)$, and the other response actions (average $r=-.07, n s$ ).

\section{DISCUSSIOI}

These research results continue the examination of the effects of graphical tornado warning displays on risk perception and expected protective actions. As Ash et al. ${ }^{(25)}$ noted, it is important to explore how the conventional warning polygon compares to alternative formats in influencing people's $p_{s}$ judgments and behavioral responses. Accordingly, participants in the present study viewed three different displays - a polygon-only condition, a polygon + tornadic storm cell condition, and a polygon + multiple storm cells condition. The present study design is similar to that of Ash et al. ${ }^{(25)}$ in comparing a conventional polygon to other conditions, so the discussion below compares the present results mainly with that study.

\subsection{Research Hypotheses}

Regarding RH1 (Tornado $p_{s}$ judgments will be greater at the polygon centroid than inside its lateral and far edges), Figure 2 and Table I show that the centroid (grid cell F3) received higher $p_{s}$ judgments than any of the cells inside its lateral and far edges. This result is completely consistent with previous polygon-only studies ${ }^{(3,24,25)}$ that found the centroid to have the highest $p_{s}$ judgments. It is important to avoid misinterpreting the results for this hypothesis as an unqualified replication of the centroid effect found in polygon-only studies, in which the polygon centroid inappropriately received higher $\boldsymbol{p}_{\mathrm{s}}$ judgments than grid cells at the polygon's near edge. This centroid effect is addressed in $\mathrm{RH} 5$.

The strong support for $\mathrm{RH} 2$ (Tornado $p_{s}$ judgments will be greater just inside the polygon than just outside it) replicates previous findings of a weak edge effect, in which participants ignore the NWS's guidance that a polygon's boundary is a critical threshold for appraising their risk. However, although grid cells just inside the polygon generally had higher mean ratings than grid cells just outside the polygon, some that were just outside the polygon received very high $p_{s}$ judgments if they were near the tornadic storm cell. These results are similar to those of Ash et al. ${ }^{(25)}$ in which participants failed to perceive the edge of a polygon as a critical threshold.

The support for RH3 (Tornado $p_{s}$ judgments will be greater just outside the polygon than at a moderate-distance outside it) and $\mathrm{RH} 4$ (Tornado $p_{s}$ judgments will be greater at a moderate distance outside the polygon than much farther outside it) confirms that $p_{s}$ judgments decline with distance from the polygon. These results replicate those of Lindell et al. ${ }^{(3)}$ in finding substantial $p_{s}$ judgments 
and expected response actions outside the polygon and extend the results of previous studies that only examined $p_{s}$ judgments inside the polygon ${ }^{(24)}$ or inside and adjacent to it. ${ }^{(25)}$ These results also provide further support for a proximity heuristic that generates a perceived risk gradient ${ }^{(3,38)}$, which conflicts with the threshold advocated in NWS guidance. It is also consistent with the phenomenon of evacuation shadow-evacuation from areas outside an officially designated evacuation zonethat is consistently found in studies of actual evacuations. ${ }^{(4)}$

The partial support for RH5 (Tornado $p_{s}$ judgments will be highest at the polygon centroid for the polygon-only display but will be highest at the edge nearest a tornadic storm cell when a radar image is added) extends the Ash et al. ${ }^{(25)}$ results by identifying another display that weakens the centroid effect. The results in Table I comparing grid cell F3 with E2, F2, and G2 provide clear evidence that $p_{s}$ judgments at the centroid are significantly higher than those at the polygon's near edge only when the polygon is viewed in isolation. By contrast, there are no significant differences between the centroid and the polygon's near edge if a tornadic storm cell is added to the polygon display (Conditions B and C). This finding suggests that viewing a tornadic storm cell redirects participants' attention. Surprisingly, however, the addition of a tornadic storm cell only weakens, rather than eliminates, the centroid effect. Thus, providing participants with more information about the storm (i.e., the location of tornadic hook echo as well as a color-coded representation of storm intensity) was not as effective in eliminating participants' focus on the polygon centroid as the spectral and gradient displays were. ${ }^{(25)}$ The results for RH5 appear to conflict with those of Miran et al. ${ }^{(28)}$, who concluded that their participants made poorer threat assessments when radar displays were provided. Unfortunately, the basis for the apparent conflict with the present study's results is not entirely clear because Miran et al. ${ }^{(28)}$ did not report the participants' hypothesized locations in relation to the polygon. However, the differing results are likely to be due to the fact that Miran et al. ${ }^{(28)}$ reported an overall measure of accuracy rather than reporting assessments of $p_{s}$ judgments at specific points around the polygon. Thus, it is impossible to determine if their participants exhibited the centroid effect in the polygon-only conditions or assess the degree to which radar displays reduced this effect.

The results from testing RH6 (Tornado $p_{s}$ judgments will be higher outside the polygon when minor storm cells are added on either side of a tornadic storm cell) reveal that adding minor flanking storm cells produced no significant differences in $p_{s}$ judgments outside the polygon. This suggests that participants focused their attention on the cell with the hook echo and were uninfluenced by the (nonthreatening) flanking storm cells. This result is important because Condition C more nearly reproduces the radar displays of multiple storm cells that frequently accompany televised tornado warnings. However, conclusions about participants' ability to focus on the tornadic storm cell and polygon while ignoring minor storm cells must be qualified by noting that participants in this study received specific instruction about radar displays and tornado polygons immediately before judging the tornado scenarios. It remains to be determined what proportion of the tornado risk area population knows how to interpret radar displays and, thus, discriminate tornadic from nontornadic storm cells

The results for RH7 (Tornado $p_{s}$ judgments will be significantly correlated with expected response actions) confirmed previous findings that $p_{s}$ judgments were negatively correlated with continuation of normal activities and positively correlated with information seeking from a variety of 
sources and protective actions such as sheltering and evacuation. This support is crucial because the finding that $p_{s}$ judgments are related to expected protective actions means that this study has significant policy implications. For example, as noted above, the fact that $p_{s}$ judgments are positively correlated with evacuation-even though the NWS discourages this response to a tornado warning-suggests that new ways are needed to more effectively communicate tornado risks and the risks of inappropriate emergency actions.

The results from RH8 (Prior experience with tornado warnings, warning polygons, or tornado damage will be significantly related to $p_{s}$ judgments and expected response actions) revealed that all forms of experience significantly reduced expectations of evacuating. The nonsignificant correlations of prior experience with tornado polygons with $p_{s}$ judgments and expected protective actions other than evacuation differ from previous findings indicating that those who had previously seen a warning polygon were less likely to ignore tornado threats. ${ }^{(3)}$ Previous research has proposed that conflicting results regarding the effects of experience may be due to the fact that the effect of past experience depends on the lessons people draw from that experience. ${ }^{(55-57)}$ Thus, further research is needed to examine effects such as "false alarms". ${ }^{(58-60)}$ More generally, Demuth ${ }^{(61)}$ conducted a comprehensive examination of the definition and measurement of disaster experience, so future research should recognize that their studies might yield different results, depending on whether they are assessing risk personalization, personal intrusive impacts, vicarious troubling impacts, common personal threats and impacts, or negative emotional responses.

The test of RH9 (Gender and ethnicity will be significantly related to $p_{s}$ judgments and expected response actions) generated results that are only partially consistent with previous findings. ${ }^{(3)}$ Consistent with previous results, females had higher $p_{s}$ judgments and expected to shelter immediately, but females in the present study were also more likely to seek environmental cues as well as obtain information from the Internet-a contrary result. On the other hand, the results for ethnicity echoed previous findings that Whites had lower $p_{s}$ judgments and less likely to shelter or evacuate. As for the information sources, Whites were more likely to seek environmental cues.

\subsection{Research Questions}

Regarding RQ1 (What are the expected personal consequences of a tornado strike?), Table 3 suggests that participants were relatively optimistic regarding their risk of personal injury or death and, thus, were more likely to expect damage to the car than damage to the room as well as to expect damage to Juggage rather than personal injury or death. These results are consistent with previous findings ${ }^{(3)}$ and could be explained by "unrealistic optimism", which is defined as "a favorable difference between the risk estimate a person makes for him- or herself and the risk estimate suggested by a relevant, objective standard" ${ }^{(62)}$ Alternatively, they might indicate that some respondents thought the car-being outside-would be more exposed to storm wind than a person sheltering in a room and that the room might receive some damage without any occupants being injured. Further research is needed to determine which of these is the more appropriate explanation.

The results regarding RQ2 (Is there a significant correlation of the expected personal consequences of a tornado strike with $p_{s}$ judgments and expected response actions?) revealed that participants who expected room damage or personal injury/death were more likely to expect to 
evacuate. These were the only two of the 28 (four personal consequences times seven response actions) correlations that were statistically significant. Although this seven percent significance rate is larger than the one percent expected by chance, it weak evidence that warrants replication.

The results for RQ3 (Is numeracy related to $p_{s}$ judgments and expected response actions?) suggest that numeracy has no effect on people's responses to probabilistic spatial displays. Future research regarding the effects of cognitive abilities in the interpretation of tornado polygons might be more productively directed toward an examination of spatial abilities. ${ }^{(63)}$

All studies have their limitations and this one is no exception. The participants were mostly students who were from a region that is notable for the rarity of tornadoes. Only a minority (25\%) of the participants had ever received a tornado warning and those who had previously received a tornado warning had only received a few. As a specific example, the county in which the experiment was conducted has had only five tornadoes in the past 60 years and the most recent one was 2001 when the average participant would have been seven years old. Moreover, these participants were responding to hypothetical scenarios, which do not necessarily elicit the same responses as actual situations. However, many of the results in the polygon-only condition (Condition A) replicate those reported by Lindell et al. (2016) $)^{(3)}$, whose sample had a significantly higher level of tornado experience. In addition, research on hurricanes has found that experiments involving hypothetical hurricane scenarios yield results that are quite similar to those that are found in surveys of responses to actual hurricanes. ${ }^{(46)}$

Another potential limitation is that the description of the tornado scenario included a statement that there was a Tornado Warning over a three hour time interval that was more characteristic of a Tornado Watch. However, none of the participants indicated that they found this statement to be problematic, quite possibly because of their lack of experience with Watches and Warnings. Moreover, the participants in all three conditions received the same instructions so the effect (if it did exist) would have affected all three conditions equally. For the hypotheses about differences between locations ( $\mathrm{RH} 1-\mathrm{RH} 4)$ or about differences between locations that are contingent upon display (RH5 and RH6), adding or subtracting a constant to all three conditions would have no effect on the differences between the means for those conditions or the variances within those conditions. Thus, the hypotheses tested by $t$-tests or MANOVA would be unaffected. Similarly, adding or subtracting a constant to one of the variables has no effect on the correlation analyses (RH7-RH9 and $R Q 2$ and $R Q 3$ :

\section{CONCLUSIONS}

This study adds more evidence to existing literature that risk perception, operationalized here as $p_{s}$ judgments, is significantly correlated with information seeking and protective responses to imminent environmental hazards. ${ }^{(4,46)}$ Unfortunately in the case of tornadoes, $p_{s}$ judgments are positively correlated with evacuation expectations even though the NWS discourages people from taking this action when a tornado warning is in effect.

In addition, this study suggests that the addition of radar displays to the conventional deterministic tornado polygon has an effect that is similar to that of the probabilistic spectral and gradient displays in increasing $p_{s}$ judgments and protective action expectations at the near edge of tornado polygons. However, these displays only weakened rather than eliminated the centroid 
effect and produced no detectable increase in the NWS's desired edge effect (dramatically lower $p_{s}$ judgments and protective action expectations outside the polygon). Moreover, further research is needed to make more direct comparisons between the relative effects of the polygon + storm cell display versus the spectral and gradient displays. Such comparisons should also examine whether experiment participants also use a proximity heuristic to generate perceived risk gradients in response to the probabilistic displays. Collecting concurrent or post-experiment "think-aloud" data are likely to be informative in this regard. ${ }^{(64)}$

Finally, the addition of minor storm cells beyond the tornadic storm cell with a hook echo doesn't seem to make a difference in participants' $p_{s}$ judgments and expected response actions. However, it is important to note that participants in this experiment were emphatically told how to identify the hook echo as a tornado indicator at the beginning of the experiment but it is unclear what proportion of tornado risk area residents are aware of this information. In this regard, other research has found that many people are unable to distinguish some types of tornadic clouds from nontornadic clouds, ${ }^{(65)}$ which indicates that there are multiple ways in which people can misidentify tornadoes as less dangerous cloud formations. Thus, future research should continue to conduct experiments that manipulate verbal warnings, radar images, tornado polygons, and cloud formations to determine how people resolve potential information conflicts.

\section{ACKNOWLEDGEMENTS}

This article is based on work supported by the National Science Foundation under Grants IIS1212790 and IIS-1540469. Any opinions, findings, and conclusions or recommendations expressed in this material are those of the authors and do not necessarily reflect the views of the National Science Foundation. We wish to thank Harold Brooks for helpful comments on the test materials.

\section{REFERENGES}

1. Shen G, Hwang SN. A spatial risk analysis of tornado-induced human injuries and fatalities in the USA. Natural Hazards, 2015; 77:1223-1242.

2. Demuth JL, Morss RE, Lazo JK, Hilderbrand DC. Improving effectiveness of weather risk communication on the NWS Point-and-Click web page. Weather and Forecasting, 2013; 28:711726.

3. Lindell MK, Huang S-K, Wei H-L, Samuelson, CD. Perceptions and expected immediate reactions to tornado warning polygons. Natural Hazards, 2016; 80:683-707.

4. Lindell, M.K. Communicating imminent risk. In H. Rodríguez, J. Trainor, and W. Donner (eds.) Handbook of Disaster Research. New York: Springer, in press.

5. Lindell MK, Perry RW. Communicating environmental risk in multiethnic communities. Thousand Oaks CA: Sage, 2004.

6. Lindell MK, Perry RW. The Protective Action Decision Model: Theoretical modifications and additional evidence. Risk Analysis, 2012; 32:616-632.

7. Brotzge J, Donner W. The tornado warning process: A review of current research, challenges, and opportunities. Bulletin of the American Meteorological Society, 2013; 94(11):1715-1733.

8. Lindell MK, Sutter DS, Trainor JE. Individual and household response to tornadoes. International Journat of Mass Emergencies and Disasters, 2013; 31:373-383. Retrieved from www.ijmed.org. 
9. Simmons, KM, Sutter D. The Groundhog Day Florida tornadoes: A case study of high-vulnerability tornadoes. Quick Response Report 193. Boulder CO: University of Colorado Natural Hazards Center, 2007. Retrieved from www.colorado.edu/hazards.

10. Balluz, L, Schieve L, Holmes T, Kiezak S, Malilay J. Predictors for persons' response to a tornado warning: Arkansas, 1 March 1997. Disasters, 2000; 24:71-77.

11. Ripberger, JT, Silva, $\mathrm{CL}$, Jenkins-Smith $\mathrm{HC}$, James $\mathrm{M}$. The influence of consequence-based messages on public responses to tornado warnings. Bulletin of the American Meteorological Society, 2015; 96(4):577-590.

12. Hammer B, Schmidlin TW. Response to warnings during the 3 May 1999 Oklahoma City Tornado: Reasons and relative injury rates. Weather and Forecasting, 2002; 17:577-581.

13. Jauernic ST, Van Den Broeke MS. Perceptions of tornadoes, tornado risk, and tornado safety actions and their effects on warning response among Nebraska undergraduates. Natural Hazards, 2016; 80, 329-350.

14. Durage SW, Kattan L, Wirasinghe SC, Ruwanpura JY. Evacuation behaviour of households and driversduring a tornado. Natural Hazards, 2014; 71:1495-1517.

15. Paul BK, Stimers M, Caldas M. Predictors of compliance with tornado warnings issued in Joplin, Missouri in 2011. Disasters, 2014; 39:108-124.

16. Schultz DM, EC, Gruntfest MH, Hayden CC, Benight S, Drobot, Barnes LR. Decision making by Austin, Texas, residents in hypothetical tornado scenarios. Weather, Climate and Society, 2010; $2,249-254$.

17. Ripberger $\mathrm{JT}$, Silva $\mathrm{CL}$, Jenkins-Smith $\mathrm{HC}$, Carlson DE, James $\mathrm{M}$, Herron KG. False alarms and missed events. The impact and origins of perceived inaccuracy in tornado warning systems. Risk Analysis, 2015; 35:44-56.

18. Casteel, MA. Communicating increased risk: An empirical investigation of the National Weather Service's Impact-Based Warnings. Weather, Climate, and Society, 2016; 8(3), 219-232.

19. Perreault MF, Houston JB, Wilkins L. Does scary matter?: Testing the effectiveness of new National Weather Service tornado warning messages. Communication Studies, 2014; 65(5), 484499.

20. Mason JB, Senkbeil JC. A tornado watch scale to improve public response. Weather, climate, and society. 2015; $7(2): 146-58$.

21. Drost, R, Casteel M, Libarkin J, Thomas S, Meister M. Severe weather warning communication: factors impacting audience attention and retention of information during tornado warnings. Weather, Climate, and Society, 2016; 8(4), 361-372.

22. Sherman-Morris K, Lea AM. An exploratory study of the influence of severe weather radar broadcasts. Journal of Operational Meteorology, 2016; 4(8). 108-122.

23. Stokes, C, Senkbeil JC. Facebook and Twitter, communication and shelter, and the 2011 Tuscaloosa tornado. Disasters, 2017; 41(1), 194-208

24. Sherman-Morris K, Brown ME. Experiences of Smithville, Mississippi residents with the 27 April 2011 tornado. National Weather Digest, 2012; 36:93-101.

25. Ash, $\mathrm{KD}$, Schumann RL III, Bowser GC. Tornado warning trade-offs: Evaluating choices for visually communicating risk. Weather, Climate, and Society, 2014; 6:104-118.

This article is protected by copyright. All rights reserved. 
26. Klockow KE. Spatializing tornado warning lead-time: Risk perception and response in a spatiotemporal framework. Norman OK: The University of Oklahoma, 2013.

27. Casteel MA, Downing JR Assessing risk following a wireless emergency alert: Are 90 characters enoügh? Journal of Homeland Security and Emergency Management, 2015. DOI 10.1515/jhsem2015-0024

28. Miran SM, Ling C, James JJ, Rothfusz L. Comparing effectiveness of four graphical designs for probabilistic hazard information for tornado threat. In Proceedings of the Human Factors and Ergonomics Society Annual Meeting, 2016; 60(1): 2029-2033.

29. Hodler-TW Residents' preparedness and response to the Kalamazoo tornado. Disasters, 2010; 6:44-49.

30. Comstock RD, Mallonee S. Comparing reactions to two severe tornadoes in one Oklahoma community. Disasters, 2005; 29:277-287.

31. Senkbeil, JC, Rockman MS, Mason B. Shelter seeking plans of Tuscaloosa residents for a future tornado event. Weather, Climate, and Society, 2012; 4:159-171.

32. Balluz, L, Schieve L, Holmes T, Kiezak S, Malilay J. Predictors for persons' response to a tornado warning: Arkansas, 1 March 1997. Disasters, 2000; 24:71-77.

33. Blanchard-Boehm RD, Cook MJ. Risk communication and public education in Edmonton, Alberta, Canada on the 10th anniversary of the 'Black Friday' tornado. International Research in Geographical and Environmental Education, 2004; 13:38-54.

34. Liu, S, Quenemoen LE, Malilay J, Noji E, Sinks T, and Mendlein J. Assessment of a severe-weather warning system and disaster preparedness, Calhoun County, Alabama, 1994. American Journal of Public Health, 1996; 86:87-89.

35. Nagele-DE, Trainor JE. Geographic specificity, tornadoes, and protective action. Weather, Climate, and Society, 2012; 4:145-155.

36. Friedsam H. Reactions of older persons to disaster caused losses: An hypothesis of relative deprivation. The Gerontologist, 1961; 1:34-37.

37. Trainor JE, Nagele D, Philips B, Scott B. Tornadoes, social science, and the false alarm effect. Weather, Climate, and Society, 2015; 7(4):333-352.

38. Lindell MK, Earle TC. How close is close enough: Public perceptions of the risks of industrial facilities. Risk Analysis, 1983; 3:245-253.

39. Lindsay, DS. Replication in psychological science. Psychological Science, 26, 1827-1832, 2015.

40. Nosek, BA. et at. Promoting an open research culture. Science, 2015; 348(6242), 1422-1425.

41. Simmons, J.P., Nelson, L.D., \& Simonsohn, U. False-positive psychology: Undisclosed flexibility in data collection and analysis allows presenting anything as significant. Psychological Science, 2011; 22, 1359-1366.

42. Dash N, Gladwin H. Evacuation decision making and behavioral responses: Individual and household. Natural Hazards Review, 2007; 8:69-77.

43. Davidson DJ, Freudenberg WR. Gender and environmental risk concerns: A review and analysis of available research. Environment and Behavior, 1996; 28:302-339.

44. Fothergill A. Gender, risk, and disaster. International Journal of Mass Emergencies and Disasters, 1996; 14:33-56. Retrieved from www.ijmed.org.

This article is protected by copyright. All rights reserved. 
45. Chaney, PL, Weaver GS, Youngblood SA Previous experience and tornado preparedness in DeKalb County, Alabama. Papers in Applied Geography, 2015; 1:128-133.

46. Huang S-K, Lindell MK, Prater CS. Who leaves and who stays? A review and statistical metaanalysis of hurricane evacuation studies. Environment and Behavior, 2016; 48, 991-1029.

47. Lipkus $1 \mathrm{M}$, Peters E. Understanding the role of numeracy in health: Proposed theoretical framework and practical insights. Health Education \& Behavior, 2009; 36(6):1065-1081.

48. Reyna VF, Nelson WL, Han PK, Dieckmann NF. How numeracy influences risk comprehension and medical decision making. Psychological Bulletin, 2009; 135(6):943-973.

49. Keller $C$. Using a familiar risk comparison within a risk ladder to improve risk understanding by low numerates: A study of visual attention. Risk Analysis, 2011; 31(7):1043-1054.

50. Keller C, Siegrist M, Visschers V. Effect of risk ladder format on risk perception in high- and lownumerate individuals. Risk Analysis, 2009; 29(9):1255-1264.

51. Kreuzmair C, Siegrist M, Keller C. High numerates count icons and low numerates process large areas in pictographs: Results of an eye-tracking study. Risk Analysis, in press.

52. Fagerlin A, Zikmund-Fisher BJ, Ubel PA, Jankovic A, Derry HA, Smith DM. Measuring numeracy without a math test: development of the Subjective Numeracy Scale. Medical Decision Making, 2007; 27(5):672-680.

53. Little, RJA. A test of missing completely at random for multivariate data with missing values. Journat of the American Statistical Association, 1998; 83:1198-1202.

54. LeBreton, JM, Senter, JL. Answers to 20 questions about interrater reliability and interrater agreement. Organizational Research Methods, 2007;11:815-852.

55. Baker EJ. Hurricane evacuation behavior. International Journal of Mass Emergencies and Disasters 9:287-310, 1991. Retrieved from www.ijmed.org.

56. Lindell, MK. North American cities at risk: Household responses to environmental hazards. In T Rossetto, H Joffe and J Adams (Eds.). Cities at risk: Living with perils in the 21st century (pp. 109130). Dordrecht: Springer, 2013.

57. Weinstein, ND. Effects of personal experience on self-protective behavior. Psychological Bulletin, 1989; 105:31-50.

58. Dillon RL, Tinsley $\mathrm{CH}$. How near-misses influence decision making under risk: A missed opportunity for learning. Management Science, 2008; 54:1425-1440.

59. Dillon RL, Tinsley $\mathrm{CH}$, Cronin MA. Why near-miss events can decrease an individual's protective response to hurricanes. Risk Analysis, 2011; 31:440-449.

60. Tinsley, $\mathrm{CH}$, Dillon RL, Cronin MA. How near-miss events amplify or attenuate risky decision making. Management Science, 2012; 58:1596-1613.

61. Demuth, JL. Developing a valid scale of past tornado experiences. Fort Collins CO: Colorado State University Libraries, 2016.

62. Shepperd JA, Klein WMP, Waters EA, Weinstein ND. Taking stock of unrealistic optimism. Perspectives on Psychological Science, 2013; 8:395-411.

63. Hegarty, M. Components of spatial intelligence. Psychology of Learning and Motivation, 2010; $52: 265-297$.

64. Fox, MC, Ericsson KA, Best R. Do procedures for verbal reporting of thinking have to be reactive? A meta-analysis and recommendations for best reporting methods. Psychological Bulletin, 2011; 137(2): 316-344.

This article is protected by copyright. All rights reserved. 
65. Dewitt B, Fischhoff B, Davis A, Broomell SB. Environmental risk perception from visual cues: The psychophysics of tornado risk perception. Environmental Research Letters, 2015; 10(12): 124009.

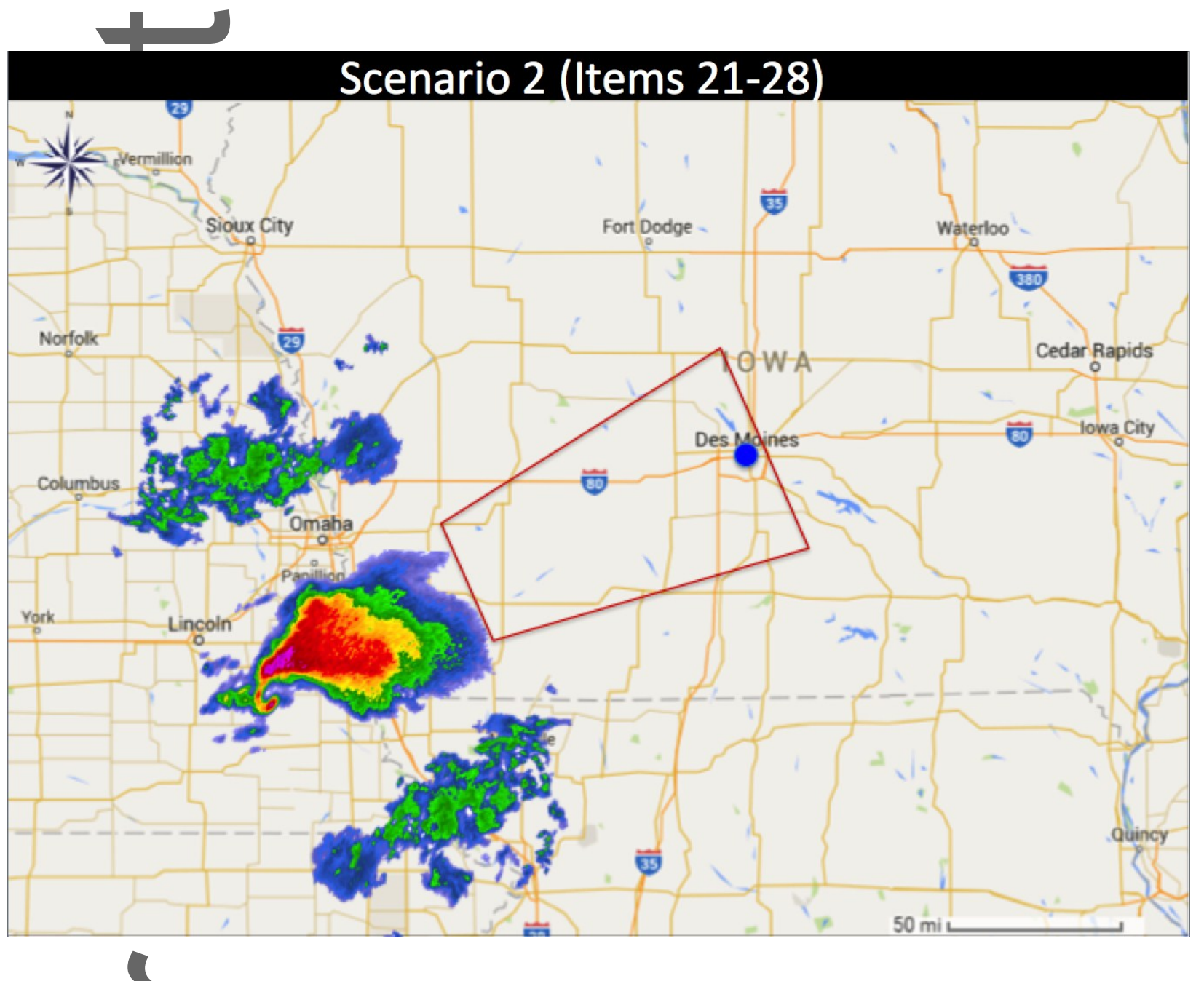

Fig. 1. Sample Display, Tornado Polygon with a Tornadic Storm Cell and Two Flanking Cells

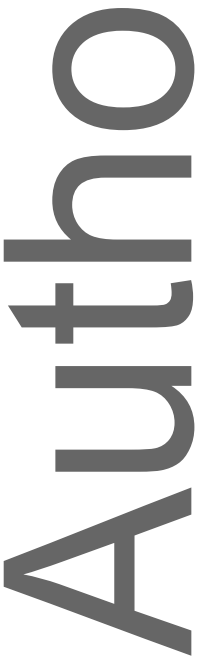

This article is protected by copyright. All rights reserved. 


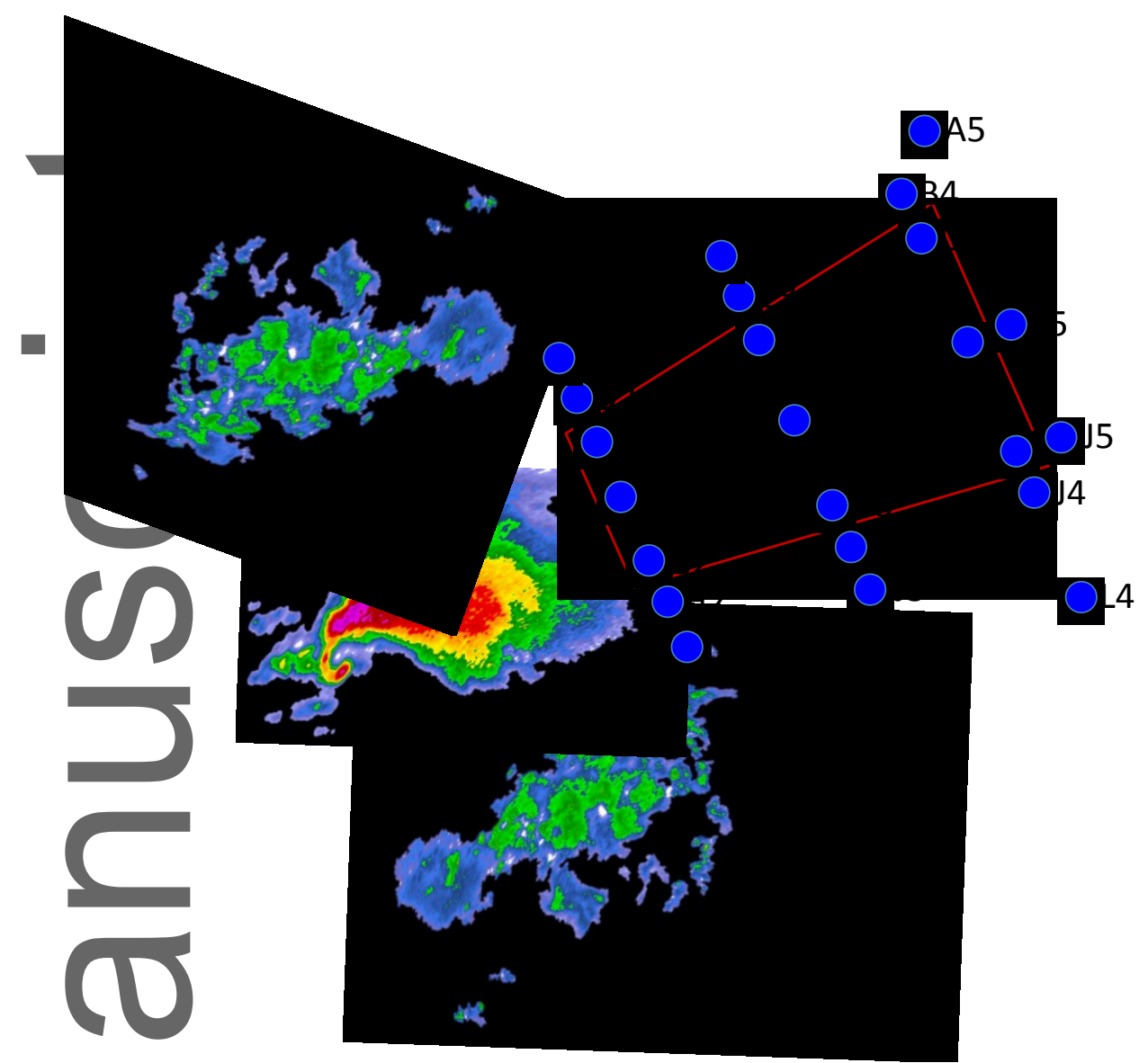

Fig. 2. Storm Cells, Warning Polygon, and the Hypothesized Locations of the Motel
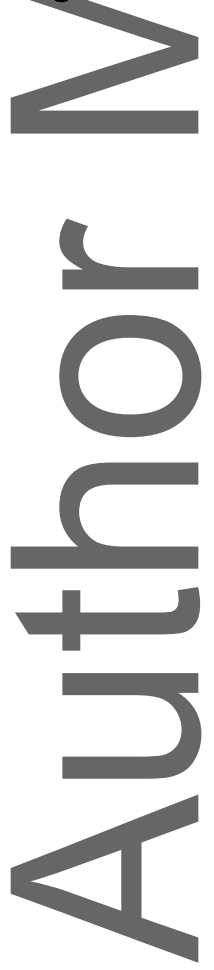

This article is protected by copyright. All rights reserved. 


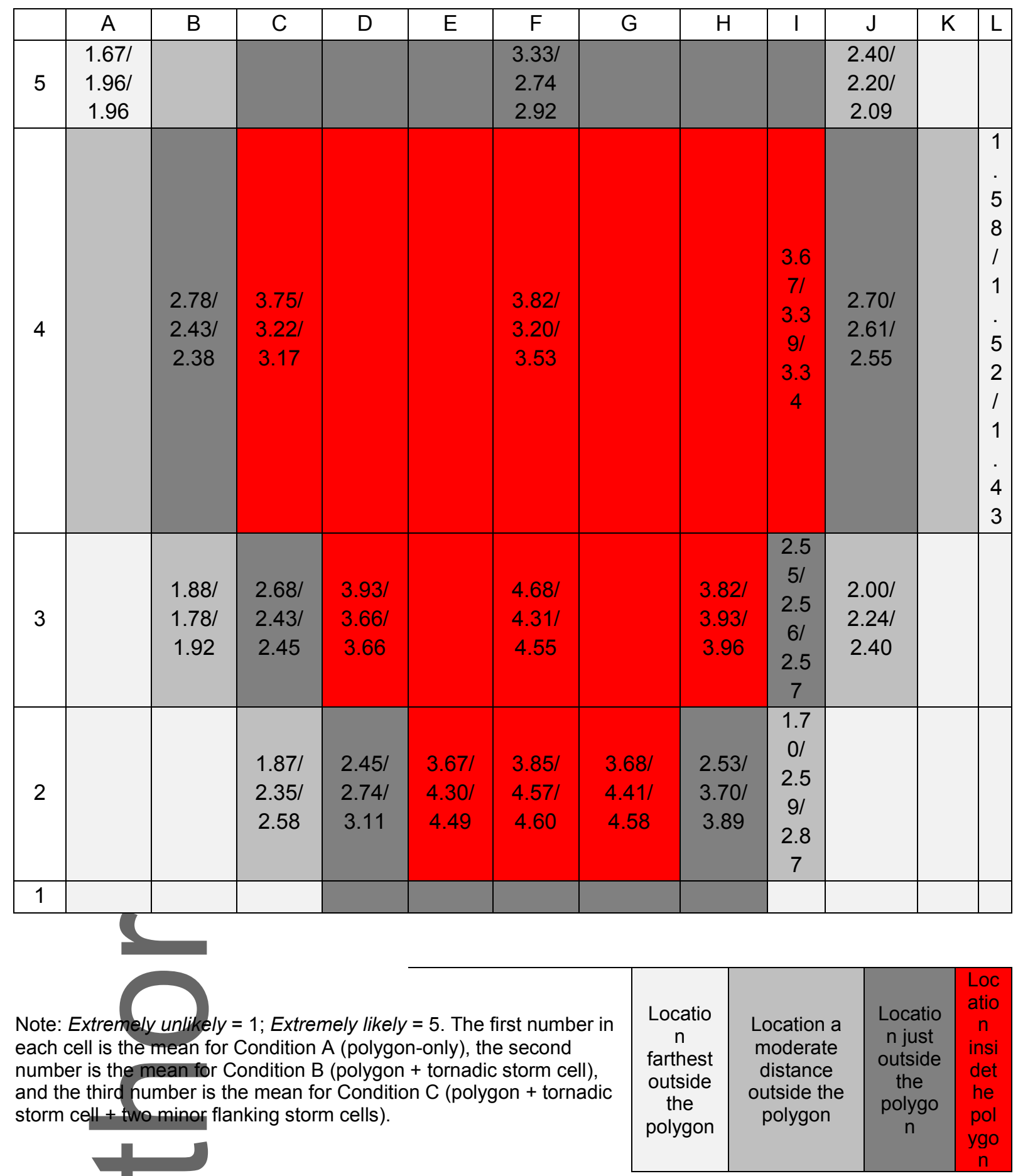

Figure 3. Participants' Mean Strike Probability Judgments, by Display and Location

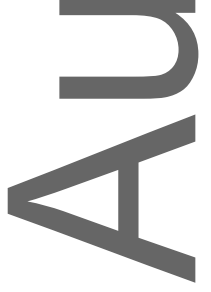

This article is protected by copyright. All rights reserved. 
Table I. Test Results for RH1-3 and RH5

\begin{tabular}{|c|c|c|c|c|c|c|}
\hline \multirow[t]{2}{*}{ Comparison } & \multicolumn{2}{|c|}{ Condition A: Polygon-only } & \multicolumn{2}{|c|}{$\begin{array}{c}\text { Condition B: Polygon + tornadic } \\
\text { storm cell }\end{array}$} & \multicolumn{2}{|c|}{$\begin{array}{l}\text { Condition C: Polygon + } \\
\text { multiple storm cells }\end{array}$} \\
\hline & & Test result & Difference & Test result & Difference & Test result \\
\hline \multicolumn{7}{|c|}{$\mathrm{RH} 1$} \\
\hline F3 > D3 & & $\begin{array}{l}t_{59}=6.23, p< \\
.001\end{array}$ & 0.65 & $t_{53}=4.49, p<.001$ & 0.89 & $\begin{array}{l}t_{52}=8.06, p< \\
.001\end{array}$ \\
\hline $\mathrm{F} 3>\mathrm{H} 3$ & & $\begin{array}{l}t_{59}=7.69, p< \\
.001\end{array}$ & 0.38 & $t_{53}=2.76, p<.01$ & 0.59 & $\begin{array}{l}t_{52}=6.16, p< \\
.001\end{array}$ \\
\hline $\mathrm{F} 3>\mathrm{C} 4$ & & $\begin{array}{l}t_{59}=7.07, p< \\
.001\end{array}$ & 1.09 & $t_{53}=7.77, p<.001$ & 1.38 & $\begin{array}{l}t_{52}=11.10, p< \\
.001\end{array}$ \\
\hline F3 > F4 & & $\begin{array}{l}t_{59}=7.09, p< \\
.001\end{array}$ & 1.11 & $t_{53}=6.59, p<.001$ & 1.02 & $\begin{array}{l}t_{52}=6.85, p< \\
.001\end{array}$ \\
\hline $\mathrm{F} 3>14$ & & $\begin{array}{l}t_{59}=8.82, p< \\
.001\end{array}$ & 0.92 & $t_{53}=6.11, p<.001$ & 1.21 & $\begin{array}{l}t_{52}=12.75, p< \\
.001\end{array}$ \\
\hline \multicolumn{7}{|c|}{$\mathrm{RH} 2$} \\
\hline E2 > D2 & & $\begin{array}{l}t_{59}=8.64, p< \\
.001\end{array}$ & 1.56 & $\begin{array}{l}t_{53}=10.63, p< \\
.001\end{array}$ & 1.38 & $\begin{array}{l}t_{52}=13.10, p< \\
.001\end{array}$ \\
\hline $\mathrm{D} 3>\mathrm{D} 2$ & & $\begin{array}{l}t_{59}=10.78, p< \\
.001\end{array}$ & 0.92 & $t_{53}=7.41, p<.001$ & 0.55 & $\begin{array}{l}t_{52}=4.37, p< \\
.001\end{array}$ \\
\hline D3 $>$ C3 & & $\begin{array}{l}t_{59}=11.31, p< \\
.001\end{array}$ & 1.23 & $t_{53}=9.54, p<.001$ & 1.21 & $\begin{array}{l}t_{52}=9.48, p< \\
.001\end{array}$ \\
\hline $\mathrm{C} 4>\mathrm{C} 3$ & & $\begin{array}{l}t_{59}=7.83, p< \\
.001\end{array}$ & 0.79 & $t_{53}=6.23, p<.001$ & 0.72 & $\begin{array}{l}t_{52}=5.00, p< \\
.001\end{array}$ \\
\hline $\mathrm{C} 4>\mathrm{B} 4$ & & $\begin{array}{l}t_{59}=8.68, p< \\
.001\end{array}$ & 0.79 & $t_{53}=5.65, p<.001$ & 0.79 & $\begin{array}{l}t_{52}=5.17, p< \\
.001\end{array}$ \\
\hline $\mathrm{F} 4>\mathrm{F} 5$ & & $\begin{array}{l}t_{59}=3.32, p< \\
.01\end{array}$ & 0.46 & $t_{53}=2.68, p<.01$ & 0.61 & $\begin{array}{l}t_{52}=3.49, p< \\
.01\end{array}$ \\
\hline $14>J 5$ & & $\begin{array}{l}t_{59}=10.48, p< \\
.001\end{array}$ & 1.19 & $t_{53}=9.54, p<.001$ & 1.25 & $\begin{array}{l}t_{52}=9.45, p< \\
.001\end{array}$ \\
\hline $14>\mathrm{J} 4$ & & $\begin{array}{l}t_{59}=8.31, p< \\
.001\end{array}$ & 0.78 & $t_{53}=6.81, p<.001$ & 0.79 & $\begin{array}{l}t_{52}=7.27, p< \\
.001\end{array}$ \\
\hline $14>13$ & & $\begin{array}{l}t_{59}=8.43, p< \\
.001\end{array}$ & 0.83 & $t_{53}=4.51, p<.001$ & 0.77 & $\begin{array}{l}t_{52}=6.48, p< \\
.001\end{array}$ \\
\hline $\mathrm{H} 3>\mathrm{I} 3$ & & $\begin{array}{l}t_{59}=8.78, p< \\
.001\end{array}$ & 1.37 & $t_{53}=8.38, p<.001$ & 1.39 & $\begin{array}{l}t_{52}=11.49, p< \\
.001\end{array}$ \\
\hline $\mathrm{H} 3>\mathrm{H} 2$ & 1.29 & $\begin{array}{l}t_{59}=9.25, p< \\
.001\end{array}$ & 0.23 & $t_{53}=1.95, n s$ & 0.07 & $t_{52}=.59, n s$ \\
\hline $\mathrm{G} 2>\mathrm{H} 2$ & & $\begin{array}{l}t_{59}=8.32, p< \\
.001\end{array}$ & 0.71 & $t_{53}=7.49, p<.001$ & 0.69 & $\begin{array}{l}t_{52}=6.56, p< \\
.001\end{array}$ \\
\hline \multicolumn{7}{|c|}{ RH3 } \\
\hline $\mathrm{D} 2>\mathrm{C} 2$ & & $\begin{array}{l}t_{59}=5.59, p< \\
.001\end{array}$ & 0.39 & $t_{53}=3.04, p<.01$ & 0.53 & $\begin{array}{l}t_{52}=4.96, p< \\
.001\end{array}$ \\
\hline $\mathrm{C} 3>\mathrm{B} 3$ & & $\begin{array}{l}t_{59}=9.06, p< \\
.001\end{array}$ & 0.65 & $t_{53}=5.46, p<.001$ & 0.53 & $\begin{array}{l}t_{52}=4.43, p< \\
.001\end{array}$ \\
\hline $13>\sqrt{3}$ & & $\begin{array}{l}t_{59}=4.42, p< \\
.001\end{array}$ & 0.32 & $t_{53}=2.05, n s$ & 0.17 & $t_{52}=1.27, n s$ \\
\hline $\mathrm{H} 2>\mathrm{I} 2$ & & $\begin{array}{l}t_{59}=6.73, p< \\
.001\end{array}$ & 1.11 & $t_{53}=9.73, p<.001$ & 1.02 & $\begin{array}{l}t_{52}=8.57, p< \\
.001\end{array}$ \\
\hline
\end{tabular}

This article is protected by copyright. All rights reserved. 


\begin{tabular}{|c|c|c|c|c|c|c|}
\hline \multicolumn{7}{|c|}{ RH5 } \\
\hline $\mathrm{F} 3>\mathrm{E} 2$ & 1.01 & $t_{59}=8.31, p<.001$ & 0.01 & $t_{53}=.12, n s$ & 0.06 & $t_{52}=.54, n s$ \\
\hline $\mathrm{F} 3>\mathrm{F} 2$ & 0.83 & $t_{59}=6.61, p<.001$ & -0.26 & $t_{53}=-1.99, n s$ & -0.05 & $t_{52}=-.62, n s$ \\
\hline F3 > G2 & 1.00 & $t_{59}=8.10, p<.001$ & -0.10 & $t_{53}=-.73, n s$ & -0.03 & $t_{52}=-.35, n s$ \\
\hline E2 > D3 & -0.26 & $t_{59}=-2.52, n s$ & 0.64 & $t_{53}=4.96, p<.001$ & 0.83 & $t_{52}=8.64, p<.001$ \\
\hline $\mathrm{E} 2>\mathrm{C} 4$ & -0.08 & $t_{59}=-.74, n s$ & 1.08 & $t_{53}=7.09, p<.001$ & 1.32 & $t_{52}=8.99, p<.001$ \\
\hline E2 > F4 & -0.15 & $t_{59}=-1.29, n s$ & 1.10 & $t_{53}=6.01, p<.001$ & 0.96 & $t_{52}=5.33, p<.001$ \\
\hline E2 > 14 & 0.00 & $t_{59}=.00, n s$ & 0.91 & $t_{53}=6.24, p<.001$ & 1.15 & $t_{52}=9.96, p<.001$ \\
\hline $\mathrm{E} 2>\mathrm{H} 3$ & -0.15 & $t_{59}=-1.45, n s$ & 0.37 & $t_{53}=2.43, n s$ & 0.53 & $t_{52}=4.67, p<.001$ \\
\hline $\mathrm{F} 2>\mathrm{D} 3$ & -0.08 & $t_{59}=-.76, n s$ & 0.91 & $t_{53}=9.12, p<.001$ & 0.94 & $t_{52}=7.57, p<.001$ \\
\hline $\mathrm{F} 2>\mathrm{C} 4$ & 0.10 & $t_{59}=.75, n s$ & 1.35 & $t_{53}=9.81, p<.001$ & 1.43 & $t_{52}=10.15, p<.001$ \\
\hline $\mathrm{F} 2>\mathrm{F} 4$ & 0.03 & $t_{59}=.26, n s$ & 1.37 & $t_{53}=10.52, p<.001$ & 1.07 & $t_{52}=6.76, p<.001$ \\
\hline $\mathrm{F} 2>14$ & 0.18 & $t_{59}=1.75, n s$ & 1.18 & $t_{53}=9.14, p<.001$ & 1.26 & $t_{52}=10.72, p<.001$ \\
\hline $\mathrm{F} 2>\mathrm{H} 3$ & 0.03 & $t_{59}=.25, n s$ & 0.64 & $t_{53}=5.33, p<.001$ & 0.64 & $t_{52}=5.31, p<.001$ \\
\hline $\mathrm{G} 2>\mathrm{D} 3$ & -0.25 & $t_{59}=-2.08, n s$ & 0.75 & $t_{53}=6.42, p<.001$ & 0.92 & $t_{52}=7.70, p<.001$ \\
\hline $\mathrm{G} 2>\mathrm{C} 4$ & -0.07 & $t_{59}=-.73, n s$ & 1.19 & $t_{53}=9.33, p<.001$ & 1.41 & $t_{52}=9.37, p<.001$ \\
\hline $\mathrm{G} 2>\mathrm{F} 4$ & -0.14 & $t_{59}=-1.00, n s$ & 1.21 & $t_{53}=7.55, p<.001$ & 1.05 & $t_{52}=6.17, p<.001$ \\
\hline $\mathrm{G} 2>14$ & 0.01 & $t_{59}=.13, n s$ & 1.02 & $t_{53}=8.51, p<.001$ & 1.24 & $t_{52}=10.36, p<.001$ \\
\hline $\mathrm{G} 2>\mathrm{H} 3$ & -0.14 & $t_{59}=-1.31, n s$ & 0.48 & $t_{53}=4.74, p<.001$ & 0.62 & $t_{52}=5.92, p<.001$ \\
\hline
\end{tabular}

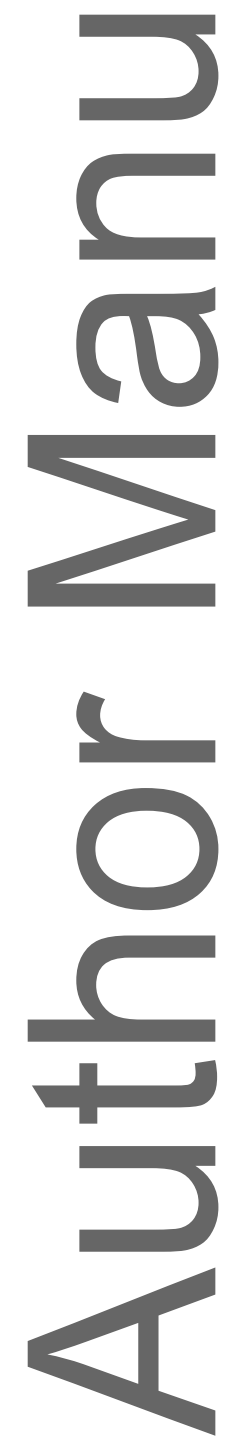

This article is protected by copyright. All rights reserved. 
Table II. Means $(M)$, Standard deviations $(S D)$, and intercorrelations $\left(r_{i j}\right)$ of variables pooled over the three display conditions.

\begin{tabular}{|c|c|c|c|c|c|c|c|c|c|c|c|c|c|c|c|c|}
\hline & $M$ & $\mathrm{SD}$ & 1 & 2 & 3 & 4 & 5 & 6 & 7 & 8 & 9 & 10 & 11 & 12 & 13 & 14 \\
\hline 1. Female & .67 & .47 & & & & & & & & & & & & & & \\
\hline 2. White & .29 & 46 & -.05 & & & & & & & & & & & & & \\
\hline 3. & 4.0 & .55 & - & .00 & & & & & & & & & & & & \\
\hline 4. & .24 & .43 & .04 & .07 & - & & & & & & & & & & & \\
\hline 5. & .20 & .40 & .07 & $.23^{*}$ & .0 & .41 & & & & & & & & & & \\
\hline 6. & .16 & .36 & .02 & .12 & .0 & .30 & .52 & & & & & & & & & \\
\hline 7. & .09 & 19 & .00 & .14 & .0 & .33 & .54 & .34 & & & & & & & & \\
\hline 8. & & 57 & $.20^{*}$ & - & - & .09 & - & - & .0 & & & & & & & \\
\hline 9. Ignore & & 69 & -.10 & -.18 & .1 & .05 & .02 & .23 & .0 & - & & & & & & \\
\hline 10. & & & $.20^{*}$ & $.20^{*}$ & .0 & - & .08 & - & .1 & $.22^{*}$ & - & & & & & \\
\hline 11. InfoTV & & 97 & -.07 & .05 & - & - & no & - & .0 & .00 & -.06 & .08 & & & & \\
\hline 12. & 8 & 1.1 & $.24^{*}$ & -.15 & - & - & - & - & - & $.27^{*}$ & - & .27 & .27 & & & \\
\hline 13. & 3.8 & 90 & .12 & .02 & .0 & - & - & - & - & $.29^{*}$ & - & .43 & .06 & .38 & & \\
\hline 14. & & 83 & $.26^{*}$ & - & - & .11 & .10 & مח & - & $.50^{*}$ & - & .35 & ח & .28 & .31 & \\
\hline $\begin{array}{l}15 . \\
\text { Evacuate }\end{array}$ & & & .14 & $.21^{*}$ & $\begin{array}{l}- \\
.0 \\
8\end{array}$ &. & $\begin{array}{c}- \\
.27 \\
*\end{array}$ & $\begin{array}{c}- \\
.36 \\
*\end{array}$ & $\begin{array}{l}- \\
.1 \\
7\end{array}$ & $.38^{*}$ & $.21^{*}$ & .10 & .28 & $\begin{array}{c}.35 \\
*\end{array}$ & .22 & $\begin{array}{l}.1 \\
8\end{array}$ \\
\hline
\end{tabular}

Significant at $p<.01$. 1. Female = respondent's gender; 2 . White = respondent's ethnicity; 3 . Numeracy = selfreported numeracy; 4. ExpPolygon = previous experience seeing a tornado warning polygon on TV; 5 .

ExpWrnAct = previous experience receiving a tornado warning and taking protective action; 6 . ExpWrnNo = previous experience receiving a tornado warning but not taking protective action; 7 . ExpTorDam = previous experience of tornado damage; 8 . StrikeProb $=p_{s}$ judgments; 9 . Ignore $=$ ignore the weather forecast and continue current activities; 10 . InfoOutside = go outside to seek environmental cues; 11. InfoTV = continue watching the weather forecast on TV; 12. Infolnternet = seek information from the Internet; 13. InfoClerk = seek information from the motel desk clerk; 14 . Shelter = seek immediate shelter; 15 . Evacuate = get into the car and evacuate.

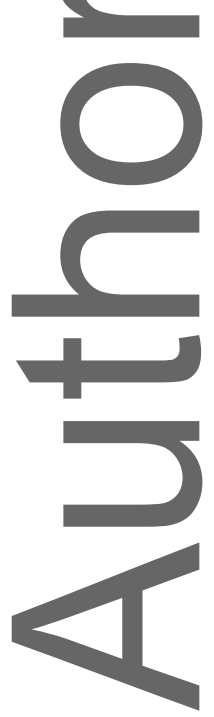

This article is protected by copyright. All rights reserved. 
Table III. Means (M), and interrater agreement $\left(r_{w G}\right)$ of expected personal consequences of a tornado strike.

\begin{tabular}{lcccc}
\hline & Car Damage & Room Damage & Luggage Damage & Injury/Death \\
\hline $\mathrm{M}$ & 4.43 & 4.20 & 3.92 & 3.61 \\
$r_{W G}$ & .62 & .61 & .43 & .41 \\
\hline & & .62 & &
\end{tabular}

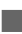

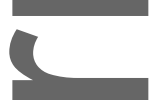

\section{Appendix A: Experiment Instructions}

\section{Severe Storm Displays}

The radar display on the right shows the amount of energy reflected back to the radar from a storm. As the scale at the bottom of the image indicates, the colors change from blue through green, yellow, orange, and red as storm intensity increases. In particular, the orange and red areas in this image have more intense rainfall and are more likely to generate tornadoes.

One especially important characteristic of a storm's radar image is a hook echo, which indicates the circular wind rotation that signals tornado formation. It is important to recognize that a hook echo is not a perfect predictor of a tornado. Some storms with hook echoes fail to produce tornadoes and some storms without hook echoes do produce tornadoes.

Moreover, storm conditions can change rapidly, so a storm might fail to develop a tornado even though early indications suggest that it might. On the other hand, a tornado might develop rapidly in another storm that did not initially appear to be threatening. Consequently, National Weather Service (NWS) meteorologists must make their best judgment about whether the available informationjustifies issuing a tornado warning.

\section{Tornado Warning Polygons}

In the past, NWS meteorologists issued tornado warnings for entire counties. However, they now issue warnings in the shape of a polygon, which is intended to warn only the locations that are most likely to experience severe weather. In the example below, the NWS issued a tornado warning that affected four counties-Tuscaloosa, Jefferson, Bibb, and Shelby (outlined in red), but the area within those four counties defined by the warning polygon (outlined in white) was much smaller.

So what does this mean for you? When you become aware of a tornado warning for your area, you need to act quickly. If it is dark and ominous, find shelter immediately. If the sun is out or the weather is benign, tune to your NOAA Weather Radio or a local radio or TV station to get more details. The NWS recommends that only those inside the polygon take action. If you are ever in doubt about whether you are at risk, seek additional weather information immediately.

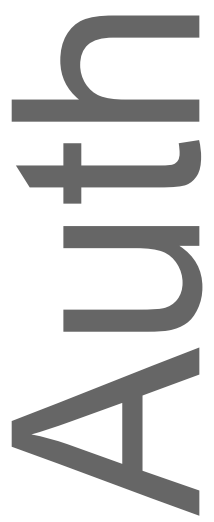

This article is protected by copyright. All rights reserved. 


\section{University Library}

\section{- M M I N E R VA A gateway to Melbourne's research publications}

Minerva Access is the Institutional Repository of The University of Melbourne

Author/s:

Jon, I;Huang, S-K;Lindell, MK

Title:

Perceptions and Expected Immediate Reactions to Severe Storm Displays

Date:

2019-01-04

Citation:

Jon, I., Huang, S. -K. \& Lindell, M. K. (2019). Perceptions and Expected Immediate Reactions to Severe Storm Displays. Risk Analysis, 39 (1), pp.274-290. https:// doi.org/10.1111/risa.12896.

Persistent Link:

http://hdl.handle.net/11343/293842 